Ann. Biol. anim. Bioch. Biophys., 1978, 18 (1), 33-43.

\title{
Age-dependent variations of somatomedin-A activity in the rabbit
}

par J. CHARRIER

Station de Physiologie animale, I.N.R.A. E.N.S.A., Place Viala 34060 Montpellier, France.

Summary. Somatomedin-A (SM-A) was assayed by Hall's method using chick embryo pelvis. The relatively high inorganic $\mathrm{SO}_{4}$ concentration of rabbit sera $(1.5 \mathrm{mM})$ interfered with the estimation of the relative potency $R$ of SM activity. Separation of the serum stimulation period from radioactive sulfate incorporation (post-incubation system) thus permitted this inconvenience to be eliminated. Using this technique we have estimated rabbit SM-A activity from birth to 180 days of age. The sera from 0 to 2-day old newborn rabbits inhibited ${ }^{35} \mathrm{SO}_{4}$ uptake by chick pelvis cartilage. We observed a transition period between 3 and 5 days of age after which the sera obtained became stimulant. SM-A activity increased slowly from 0.5 to about $1 \mathrm{U} / \mathrm{ml}$ in the age period between 10 and 180 days, but there was considerable individual variation.

$U_{P}$ to now, three kinds of chemically and biologically different somatomedins have been described (Uthne, 1973 ; Van Wyk ef al., 1973) : somatomedin-A (SM-A) which stimulates sulfate uptake by chick cartilage (Hall, 1970) ; somatomedin-B (SM-B) which stimulates DNA synthesis in human glia-like cells (Uthne, 1973), and somatomedin-C (SM-C) which stimulates sulfate uptake by rat cartilage (Van Wyck et al., 1974). The somatomedin stimulating sulfate uptake by pig rib cartilage has been called SM-P (Van den Brande and Van Buul, 1978).

For the assay of rabbit somatomedin we have modified and adapted Hall's fechnique (1970) which measures SM-A activity. We will first explain the reasons which led us to modify Hall's technique by separating the stimulation phase from the radioactive incorporation phase during in vitro incubation. Then we will report the results obtained with this technique in the newborn to 180 days old rabbit.

\section{Material and methods.}

Pelvis. - Chick pelvis leaflets were obtained by dissection of 11-day old embryos.

Incubation medium. - Hall's synthetic medium buffered with $50 \mathrm{mM}$ Hepes was used after adjustment of serine up to $0.35 \mathrm{mM}$ and of glutamine up to $0.70 \mathrm{mM}$ (Hall, 1970); $\mathrm{pH}$ was raised to 7.45 by addition of $\mathrm{NaOH}$. Streptomycin sulfate $(200 \mathrm{mg} / \mathrm{l})$, penicillin $(200.00 \mathrm{IU} / \mathrm{I})$, and amphotericin $B(20 \mathrm{mg} / \mathrm{l})$ were added to the medium. 
Sera. - We used New Zealand male rabbits, except during the stages from birth to 10 days in which the sex was undetermined. The sera were obtained by cardipunction. After coagulation for 10-15 min at room temperature, the blood was centrifuged during $15 \mathrm{~min}$ at $1800 \mathrm{~g}$. All samples were stored at $-25^{\circ} \mathrm{C}$ until assayed.

Heating. - The sera were diluted 50/50 ( $\mathrm{v} / \mathrm{v})$ with Hall's medium and the $\mathrm{pH}$ lowered to 5.5 with $\mathrm{HCl}$. They were then placed in stoppered flasks in a cool waterbath which was brought to $100^{\circ} \mathrm{C}$ and left boiling for $15 \mathrm{~min}$. The samples were centrifuged after cooling, the proteic clot discarded and the supernatant obtained brought to the initial volume by addition of distilled water. The $\mathrm{pH}$ was again raised to 7.45 with $\mathrm{NaOH}$.

Sulfate concentrations. - The mean plasmatic inorganic sulfate concentration in rabbit is about $1.5 \mathrm{mM}$ (108-270 $\mathrm{mg} / \mathrm{l}$; Brown and Lewis, 1941). The range of individual variation is therefore around $1.6 \mathrm{mM}$. In order to test the effect of serum sulfate concentration on ${ }^{35} \mathrm{SO}_{4}$ uptake, we added 0.9 and $1.5 \mathrm{mM} \mathrm{Na}_{2} \mathrm{SO}_{4}$ to our standard serum, thus permitting a variation of physiological range.

Incubation method. - The SM bioassay was carried out either by simultaneous incubation of serum and radioactive tracer or in two operations. In the first operation, stimulation was achieved by Hall's medium added with serum, and in the second, the leaflets were transferred to Hall's medium without serum and post-incubated in the presence of the tracer alone.

Simultaneous incubation was carried out in a 20-hour water-bath, agitated for $30 \mathrm{~s}$ every $15 \mathrm{~min}$. The post-incubation method demanded $20 \mathrm{hrs}$ of incubation and $4 \mathrm{hrs}$ of post-incubation. At the end of the incubation period, the leaflets were boiled, let stand overnight in saturated $\mathrm{Na}_{2} \mathrm{SO}_{4}$, rinsed for $3 \mathrm{hrs}$ in running water, individually hydrolysed in $0.25 \mathrm{ml}$ Solvene ${ }^{\circledR}$ (Packard) and measured for radioactivity in a classical scintillation medium PPO-POPOP-toluene.

Statistical analysis. - Statistical analysis was done using covariance of the 4-point bioassay (Finney, 1964); for computation we used an HP 10 computer programmed for this operation.

\section{Results.}

Post- and simultaneous incubation.

Table 1 shows that estimation of SM activity of a same serum changes depending on which of the two types of incubation is used.

The addition of sulfate provokes a steady drop of the cartilage incorporation in simultaneous incubation according to the serum concentration. No modification in the incorporation was observed with post-incubation (fig. 1). This is expressed at the relative potency $R$ estimation level by an apparent drop in activity with the simultaneous method and by maintenance of $1 \mathrm{U} / \mathrm{ml}$ activity with post-incubation (table 2). Assay accuracy, estimated by $\lambda$ Gaddum's index, was always better with post- than with simultaneous incubation. Therefore, post-incubation was systematically used to estimate SM-A activity in rabbit. 


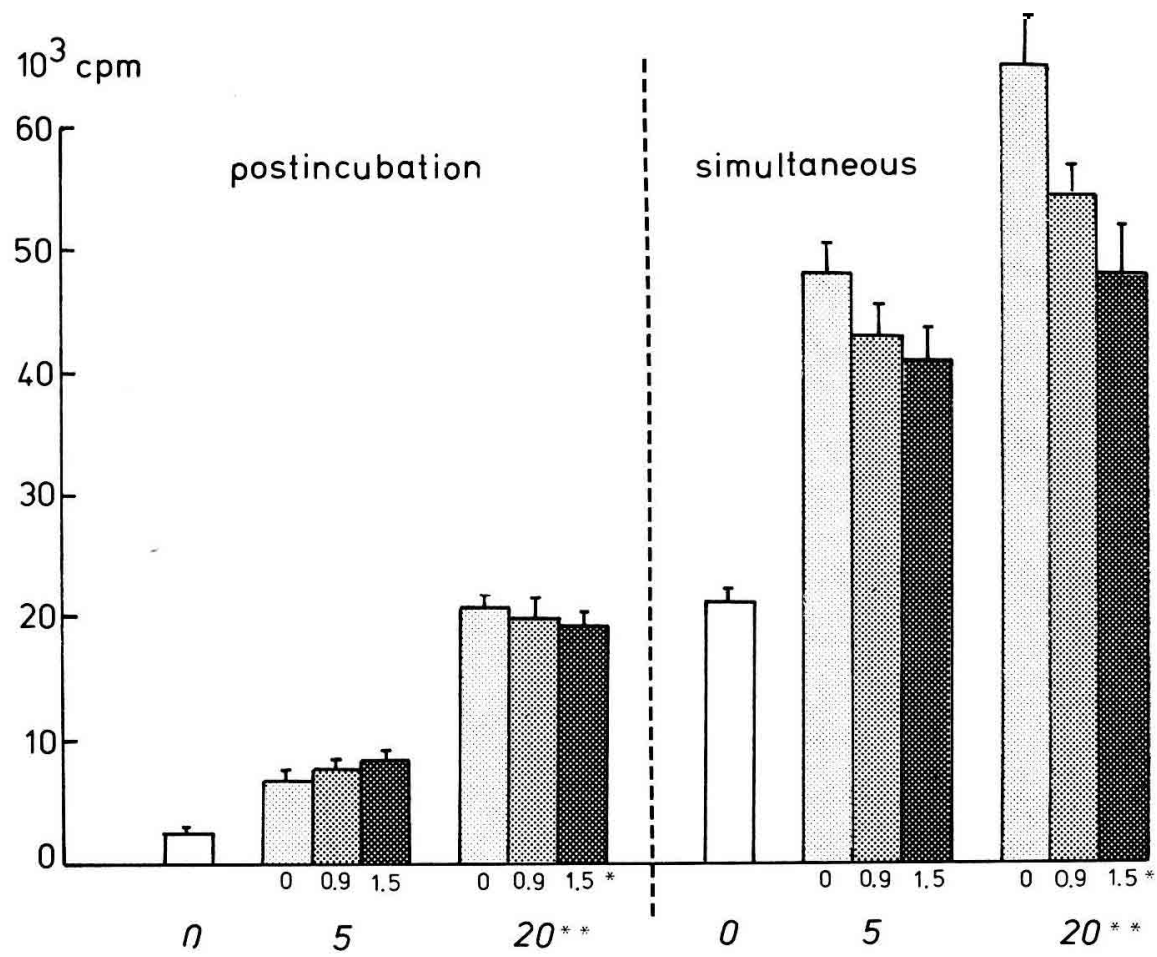

FIG. 1. - Effect of addition of cold $\mathrm{SO}_{4}$ to rabbit standard serum on the uptake of ${ }^{35} \mathrm{SO}_{4}$ by chick pelvis (Mean \pm standard-error).

* $\mathrm{mM}$ added cold $\mathrm{SO}_{4}$

** p. 100 serum concentration

(white : incorporation by controls in buffer alone)

TABLE 1

Relative potency $R$ estimation expressed in $U / \mathrm{ml}$ of rabbif or human serum SM-A activity in simultaneous or post-incubation systems (limit of confidence in brackets)

\begin{tabular}{|c|c|c|c|}
\hline & Serum & Simultaneous incubation & Post-incubation \\
\hline Rabbit & 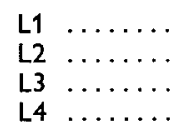 & $\begin{array}{l}0.84(0.54-1.45) \\
1.04(0.72-1.61) \\
1.03(0.74-1.56) \\
0.94(0.63-1.57)\end{array}$ & $\begin{array}{l}1.25(0.84-1.76) \\
1.33(0.97-1.78) \\
0.58(0.38-0.85) \\
0.49(0.31-0.74)\end{array}$ \\
\hline Human & $\begin{array}{c}\mathrm{JA} \ldots \ldots \\
\mathrm{CB} \ldots \ldots \\
\mathrm{JC} \ldots \ldots \\
\mathrm{MV} \ldots \ldots\end{array}$ & $\begin{array}{l}0.51(0.02-1.61) \\
0.71(0.31-1.36) \\
0.73(0.30-1.46) \\
0.82(0.36-1.61)\end{array}$ & $\begin{array}{l}0.70(0.53-0.88) \\
0.78(0.52-1.13) \\
1.16(0.91-1.48) \\
0.60(0.42-0.80)\end{array}$ \\
\hline
\end{tabular}


Somatomedin-A activity in rabbit.

Figure 2 shows the variation of SM-A activity in the 10 to 180-day old rabbit. Each stage evidences great individual variability, and a slow progression of activity from $0.5 \mathrm{U} / \mathrm{ml}$ at 10 days to $1 \mathrm{U} / \mathrm{ml}$ at 180 days is also observed.

The period from birth to 10 days of age can be divided into 3 parts (fig. 3 ) :

- 0-2 days : almost all sera inhibit $\mathrm{SO}_{4}$ uptake,

- 3-5 days : one-half of the sera are inhibitors,

$->5$ days : all the sera are stimulators.

\section{TABLE 2}

Estimation of the relative potency $(R)$ of sulfate enriched sera in the two incubation systems (limits of confidence in brackets)

\begin{tabular}{|c|c|c|}
\hline \multirow{2}{*}{ Added $\mathrm{SO}_{1}$} & \multicolumn{2}{|l|}{$\mathbf{R}$} \\
\hline & Simultaneous incubation & Post-incubation \\
\hline $\begin{array}{r}0 \ldots \ldots \ldots \\
90 \mathrm{mM} \\
150 \mathrm{mM} \ldots \ldots \ldots\end{array}$ & $\begin{array}{l}1.00 \\
0.45(0.15-0.87) \\
0.22(0.02-0.54)\end{array}$ & $\begin{array}{l}1.00 \\
1.01(0.82-1.25) \\
1.00(0.84-1.18)\end{array}$ \\
\hline
\end{tabular}

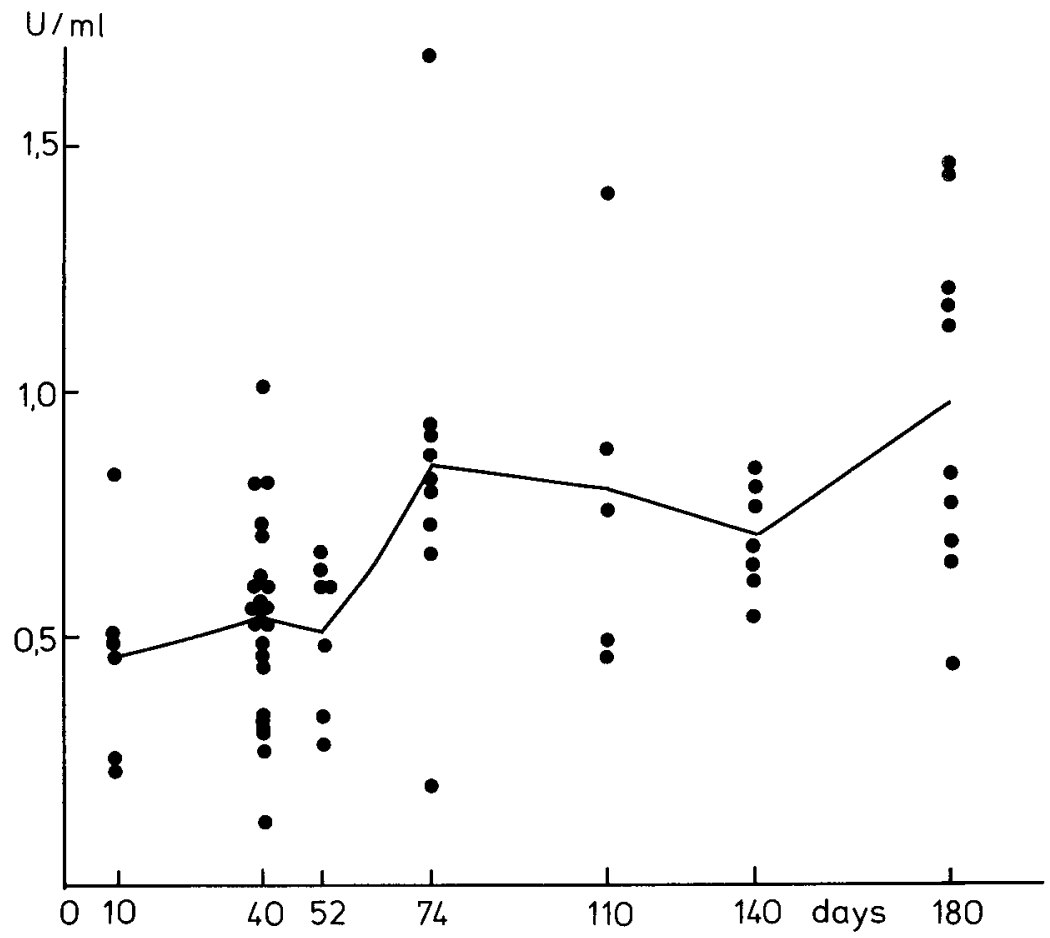

FIG. 2. - Rabbit serum SM-A activity expressed in $U / \mathrm{ml}$ in relation to age from 10 to 180 days. Each point is an individual value. The line corresponds to the mean. 


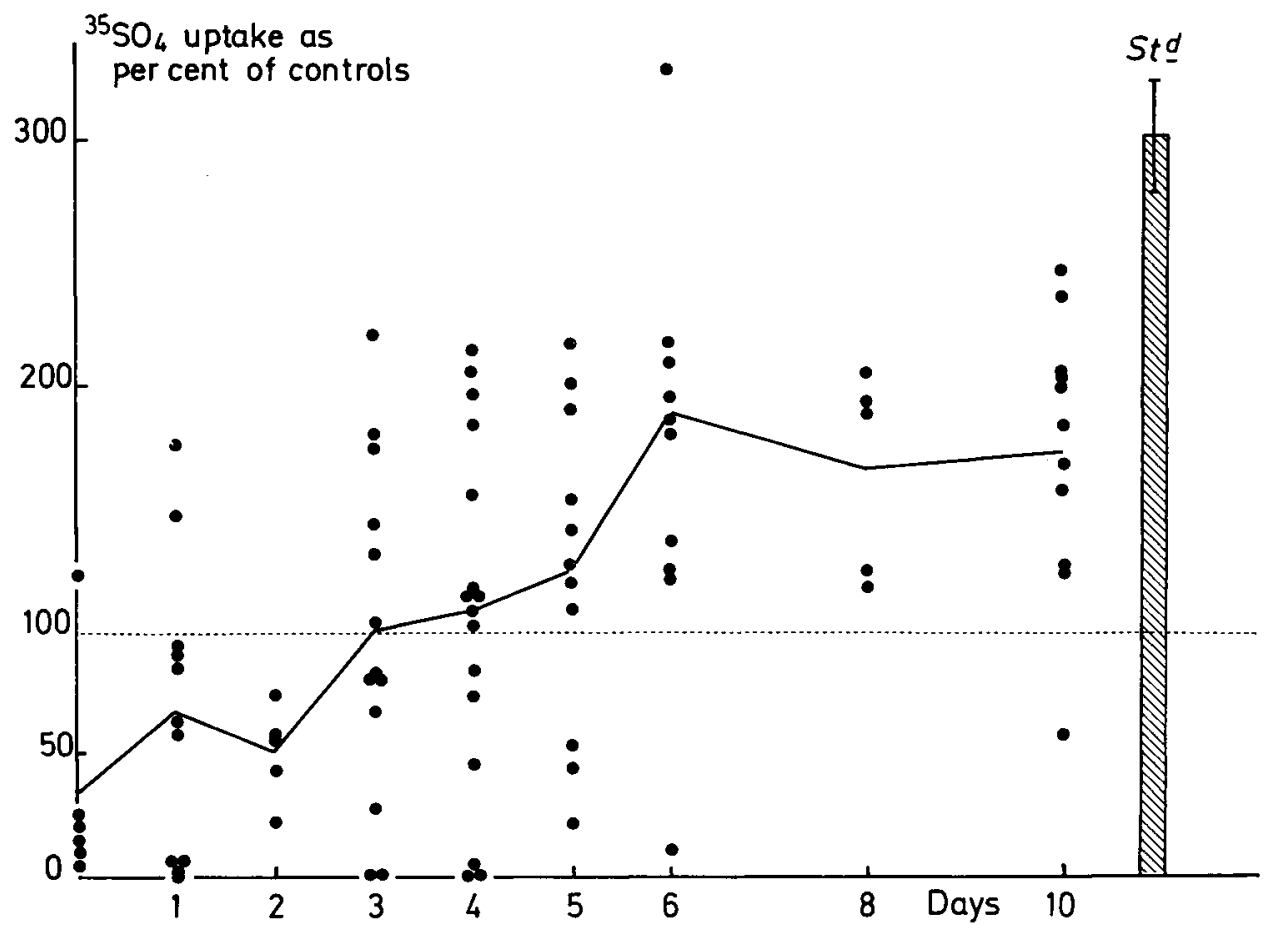

FIG. 3. - Effect of newborn rabbit serum on ${ }^{35} \mathrm{SO}_{4}$ uptake into chick pelvis. Incorporation is expressed as p. 100 incorporation produced by 10 p. 100 serum compared to buffer. Each point is an individual value. The line corresponds to the mean, and the dotted line to the control level. For comparison mean uptake obtained with the same serum concentration of our standard is shown during 15 successive assays.

In order to confirm the inhibitory effect of newborn rabbit serum, we made if react when mixed with our standard serum (fig. 4), and observed the stimulation caused by the standard at concentrations of 5 and 10 p. 100, the inhibitory effect of a pool of 0-day serum at the same concentrations, and the results obtained by mixing

\section{TABLE 3}

Effect of $100^{\circ} \mathrm{C}$ heating for $15 \mathrm{mn}$ at $\mathrm{pH} 5.5$ on rabbit serum SM-A activity. In each case the serum activity before heating is considered equal to one unit. Comparison between the two incubation systems.

\begin{tabular}{lccccc}
\hline & \multicolumn{2}{c}{ Simultaneous } & incubation & \multicolumn{2}{c}{ Post-incubation } \\
\hline & Unheated & Heated & Unheated & Heated \\
\hline Standard $\ldots \ldots \ldots$ & 1 & 0.36 & 1 & 0.48 \\
\hline Serum $1 \ldots \ldots \ldots$ & 1 & 0.38 & 1 & 0.44 \\
\hline Serum $2 \ldots \ldots \ldots$ & 1 & 0.29 & 1 & 0.34 \\
\hline
\end{tabular}




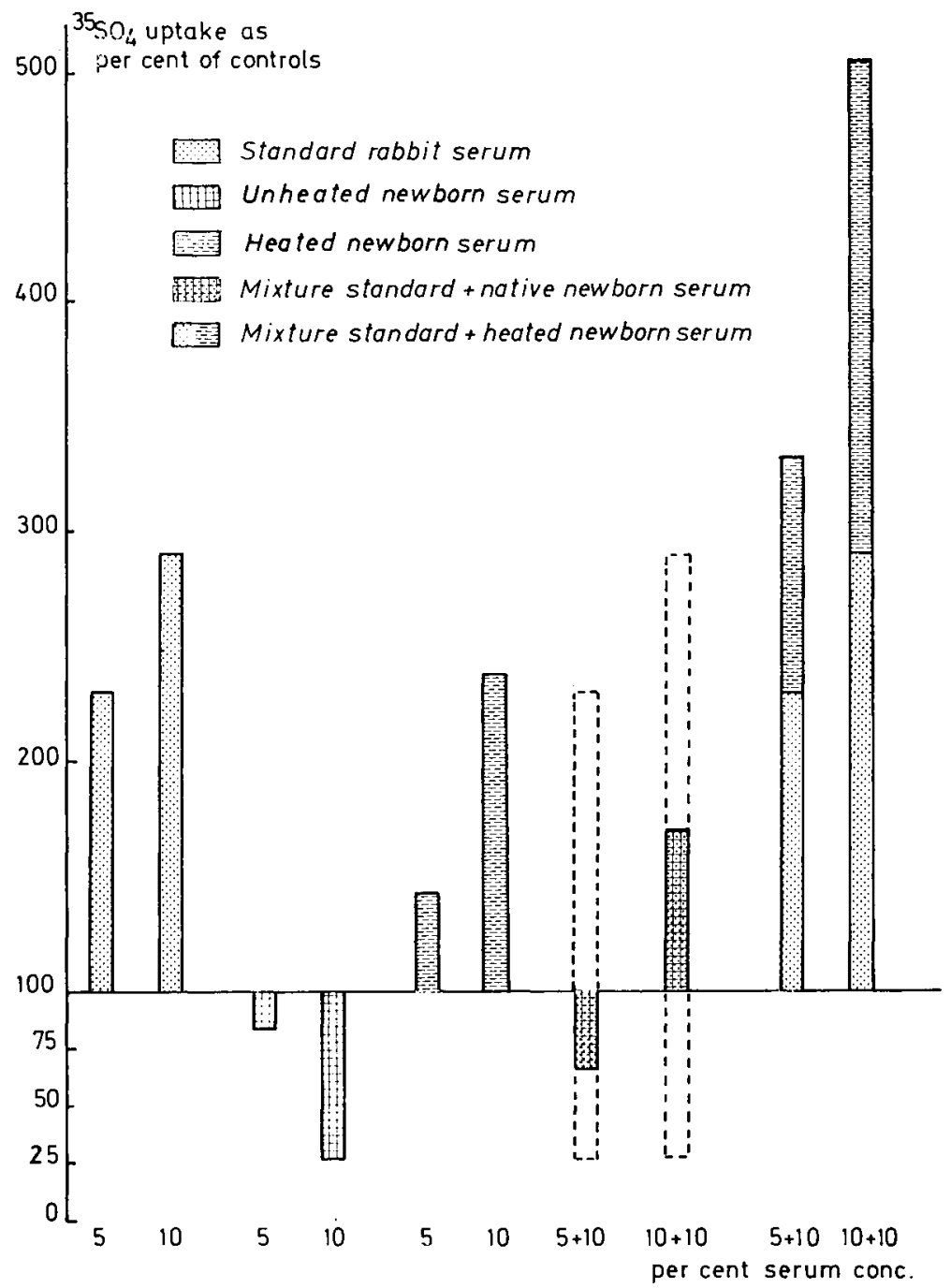

FIG. 4. - Heat suppression of the inhibitory activity of newborn rabbit sera. Results are expressed as p. 100 incorporation produced by 5 or 10 p. 100 serum compared to buffer.

both sera. It is obvious that the 0 -day serum inhibited the activity of the standard. We noted that after heat treatment, both sera became stimulators and their action additive. We would like to point out that the heating conditions $(100 \mathrm{\circ} \mathrm{C}$ at $\mathrm{pH} 5.5)$ not only eliminated the inhibitory effect, but also a part (50 to 70 p. 100) of the original SM activity (table 3 ).

The factor inhibiting sulfation by chick embryo pelvis chondroitin also blocks DNA synthesis. Figure 5 shows that ${ }^{3} \mathrm{H}$-Thy incorporation decreases in the presence of inhibitory serum in both the methods used. 


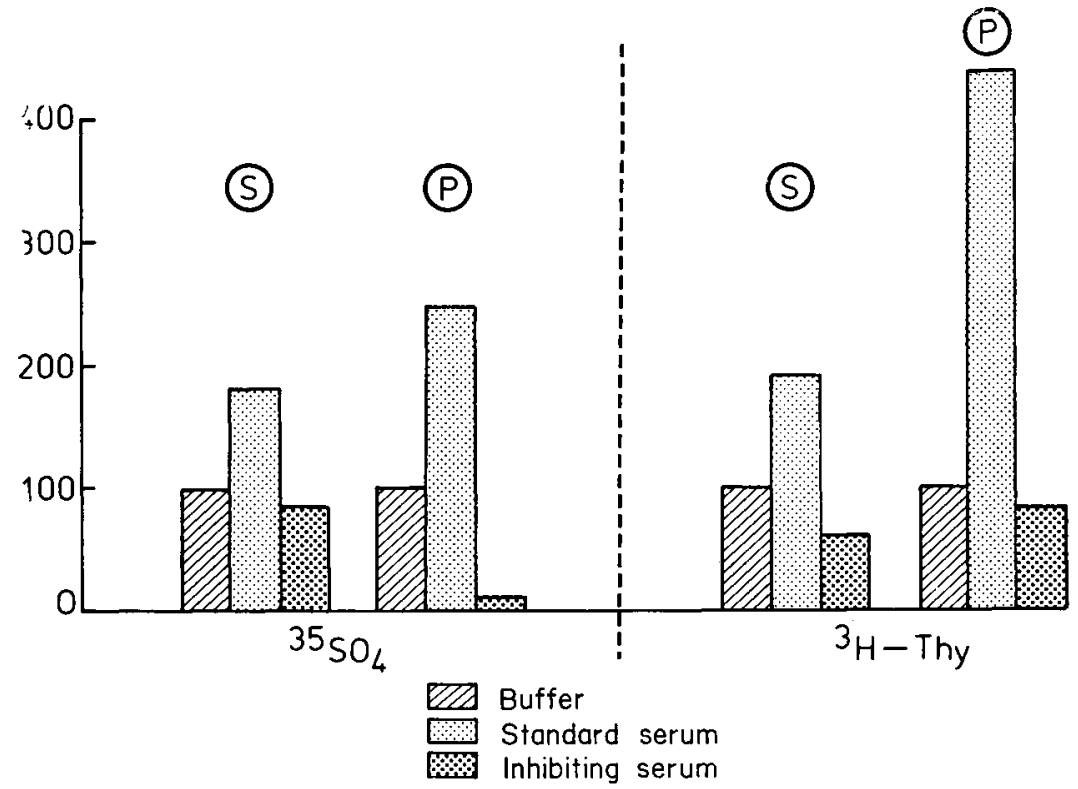

FIG. 5. - ${ }^{35} \mathrm{SO}_{4}$ or ${ }^{3} \mathrm{H}$-Thy uptake by pelvis. Incorporation is expressed as p. 100 incorporation produced by 10 p. 100 standard or inhibiting serum compared to buffer. Eight pelvises in each group.

$$
S=\text { simultaneous incubation } P=\text { post-incubation. }
$$

\section{Discussion.}

Most somatomedin bioassays deal with the incorporation of radioactive sulfate $\left({ }^{35} \mathrm{~S}\right)$ by the cartilage chondroitin. Serum sulfates would not present a problem in estimating relative potency $(R)$ if all sera contained the same sulfate concentration as the standard. However, this is not the case. High serum concentrations can produce wide variations in the inorganic sulfate pool of the incubation medium, and we showed that in rabbit individual variations in serum sulfate concentrations could affect the $R$ estimation. Because constant amounts of ${ }^{35} \mathrm{~S}$ are added to the medium, it is evident that there will be an inverse relationship between the serum concentration and the specific radioactivity of the incubation medium. The importance of this parameter has been emphasized by Daughaday et al. (1959) and more recently by Audhya and Gibson (1974). Several authors attempted to overcome this problem in different ways. Phillips et al. (1974) standardized the sulfate concentration present in the serum and incubation medium. Schimpff and Donnadieu (1973) buffered the serum $\mathrm{SO}_{4}$ differences by a bulk supplementation of inorganic sulfate to the incubation medium ; however, in this case, the specific radioactivity decreased to very low values, inducing a weak radioactive incorporation and finally a long counting time. A third solution is to process the incorporation of the radioactive precursor during a post-incubation phase without the presence of the serum (Salmon and Du Vall, 1970a and $b$; Van den Brande and Du Caju, 1974). Under our experimental conditions, this solution totally eliminates the influence of the physiological variation of serum sulfates. 
Data are scarce on SM activity in growing animals. Recently, Stuart ef al. (1976) reported that the SM activity found in rat by the costal rat assay, was measurable only at low levels until 11 days after birth and thereafter remained steady throughout life. In pigs, a positive correlation between body length and serum SM-A activity has been demonstrated (Lund-Larsen and Bakke, 1975). In young bulls, SM-A activity has been correlated with the rate of weight gain and linear growth (Lund-Larsen ef al., 1977).

SM activity variations due to aging have been studied up to now mainly in humans. A weak « sulfation factor 》 activity in newborn children was reported a long time ago by several authors (Daughaday et al., 1959 ; Almquist and Rune, 1961 ; Chesley, 1962 ; Daughaday and Parker, 1963 ; Kogut ef al., 1963). Using the pig cartilage assay, Tato ef al. (1975) found a weak SM activity up to $10 \mathrm{hrs}$ after birth, then at 4 to 5 days a peak equal to that of the adult which dropped to lower values during the following days and months. These authors could not, therefore, demonstrate any inhibitory effect in those sera of low SM activity. Using the same technique, Hintz ef al. (1974b) reported an average activity of $0.5 \mathrm{U} / \mathrm{ml}$ in cord plasma in 52 full-term newborns, showing simultaneous weak SM activity and high $\mathrm{GH}$ concentration. By incorporation of ${ }^{35} \mathrm{SO}_{4}$ in rat costal cartilage, Giordano ef al. (1976) confirmed these results in a group of 16 newborn babies.

With the chick embryo pelvis assay, Kastrup and Andersen (1975) reported a SM activity of $0.7 \mathrm{U} / \mathrm{ml}$ in the full-term newborn and of $0.3 \mathrm{U} / \mathrm{ml}$ in premature babies. These values stabilized after 6 days of age to the normal value of a 6 -month old baby. With the same technique, Pierson ef al. (1976) reported weak SM activities in newborns less than 10 days old. Therefore, weak SM activity in humans from birth to the next few days afterwards has been consistently reported in the literature. Although low, the reported values are all positive, and up to now no negative value has been reported in any species under normal biological conditions. This is the case of the newborn rabbit in which negative SM activity induces weaker incorporation of radioactive precursor by the cartilage under the action of the serum than in the control cartilage.

More elaborate techniques like the radio receptor assay only react to the stimulatory effect. By developing the RRA for SM-A, Takano et al. (1975) recently confirmed that SM-A activity in children under 2 years old does not reach 50 p. 100 of adult values. It is remarkable on the contrary that SM-B activity assayed by radioimmunoassay remains at the same level in human at one day, one week, one year and twenty years of age. It only decreases at 40 years of age when it declines to one-half of the value it had in the 20-year old (Hall et al., 1976).

At present, we do not know the exact nature of the inhibitory factor in newborn rabbit serum. However, several hypotheses can be postulated. Non-esterified straight chain fatty acids inhibit the protein synthesis mechanism only on SM-stimulated cartilage ; they have no effect on non-stimulated cartilage (Delcher ef al., 1973). Nevertheless, since newborn rabbit serum induces lower $\mathrm{SO}_{4}$ uptake than in the control, the hypothesis of free fatty acid intervention is invalidated. A second hypothesis may concern prostaglandins A. Eisenbarth (1974) demonstrated the strong inhibitory effect of these substances on sulfation with either stimulated or inactivated chick pelvis chondroitin. Thirdly, glucocorticosteroid action may be a possibility; these substances 
are known as strong cartilage metabolism inhibitors, effective $\epsilon$ ven at concentrations utilized at SM assay (Eisenbarth, 1974).

Lastly, plasmatic factors of a proteic nature, which are thermolabile and destroyed by trypsin, have also been reported to inhibit in vitro cartilage metabolism (Salmon, 1972 ; Garland ef al., 1972). However, heat suppression of the inhibitory power of newborn rabbit serum is not a specific enough procedure to assign it to this category of proteic inhibitors.

Since the heat treatment brings about a strong diminution of serum SM activity, a possible explanation could be that blood SM is protein-bound (Hintz, 1974a). When heated to $100 \circ \mathrm{C}$ all proteins are precipitated and therefore, so is all the protein-bound $S M$; only the free SM remains in the liquid phase.

Finally, we must underline that SM-A assay in mammals implicates the use of chick cartilage. It may be that newborn rabbit serum contains a factor inhibiting in vitro sulfation by chick pelvis chondroitin, which does not necessarily inhibit mammal cartilage and a fortiori rabbit cartilage. This point needs to be clarified.

Réunion Groupe Développement INRA/Productions animales Montpellier, 17-18 mai 1977.

Résumé. La méthode de Hall (1970) basée sur l'incorporation in vitro de ${ }^{35} \mathrm{SO}_{4}$ dans le pelvis d'embryon de poulet a été utilisée pour doser l'activité somatomédine $A(S M-A)$ du sérum de lapin. La concentration en $\mathrm{SO}_{4}$ inorganique du sérum de lapin est relativement élevée $(1,5 \mathrm{mM})$. Par enrichissement de notre sérum standard avec de faibles quantités de sulfate, d'ordre physiologique, nous montrons que l'effet perturbateur introduit est suffisant lorsque le sérum et le traceur sont simultanément en présence pour altérer l'estimation de l'activité SM-A du sérum. Donc les variations plasmatiques individuelles de concentration en sulfate sont-elles aussi suffisantes pour entraîner une estimation erronée de l'activité SM-A. La séparation dans le temps de la phase de stimulation par le sérum ef de la phase d'incorporation radioactive (appelée post-incubation) permet d'éliminer cet inconvénient. L'utilisation de cette technique a permis l'estimation de l'activité SM-A chez le lapin de la naissance à l'âge de 180 jours. De la naissance à 2 jours, les sérums sont inhibiteurs de l'incorporation de ${ }^{35} \mathrm{SO}_{4}$ dans le cartilage pelvien. De 3 à 5 jours existe une période de transition au-delà de laquelle les sérums deviennent stimulateurs. Entre 10 et 180 jours l'activité $S M-A$ augmente lentement de $0,5 \mathrm{U} / \mathrm{ml}$ à $1 \mathrm{U} / \mathrm{ml}$, avec une variabilité individuelle élevée. II est possible de supprimer par la chaleur le pouvoir inhibiteur des sérums de lapin nouveau-né ; mais un tel traitement réduit en même temps de 50 à 70 p. 100 l'activité SM-A.

\section{References}

ALMQVIST S., RUNE I., 1961. Studies on sulfation factor (SF) activity of human serum. The variation of serum SF with age. Acto endocr. $(K b h), 36,566$.

AUDHYA T. K., GIBSON K. D., 1974. Serum inorganic sulfate and apparent somatomedin activity in an assay using chick embryo cartilage. Endocrinology, 95, 1614-1620.

BROWN B. H., LEWIS H. B., 1941. J. biol. Chem., 138, 705. In DITTMER D. S., 1961. Blood and other body fluids, Biol. Handbooks, Fed. amer. Soc. exp. Biol., Washington DC, p. 36.

CHESLEY L. C., 1962. Growth hormone activity in human pregnancy. I. Serum sulfation factor. Am. J. Obstet. Gynec., 84, 1075-1080.

DAUGHADAY W. H., PARKER M. L., 1963. Sulfation factor measurement as an aid in the recognition of pituitary dwarfism. J. clin. Endocr., 23, 638. 
DAUGHADAY W. H., PARKER M. L., 1965. Human pituitary growth hormone. Annu. Rev. Med., 16, 47-66.

DAUGHADAY W. H., SALMON W. D., ALEXANDER F., 1959. Sulfation factor activity of sera from patients with pituitary disorders. J. clin. Endocr. Metab., 19, 743-758.

DELCHER H. K., EISENBARTH G. S., LEBOVITZ H. E., 1973. Fatty acid inhibition of sulfation factor stimulated ${ }^{35} \mathrm{SO}_{4}$ incorporation into embryonic chicken cartilage. J. biol. Chem., 248, 1901-1905.

EISENBARTH G. S., 1974. Hormonal regulation of cartilage metabolism. Thesis Ph. D., Duke University., North Carolina, USA.

FINNEY D. J., 1964. Statistical method in biological assay. $2^{\mathrm{e}}$ ed., Griffin, London.

GARLAND J. T., LOTTES M. E., KOZAK F., DAUGHADAY W. F., 1972. Stimulation of DNA synthesis in isolated chondrocytes by SF. Endocrinology, 90, 1086-1090.

GIORDANO G., FOPPIANI E., MINUTO F., PERRONI D., 1976. Growth hormone and somatomedin behaviour in the newborn. Acta. endocr., 81, 449-454.

HALL K., 1970. Quantitative determination of the sulfation activity in human serum. Acta endocr. $(K b h), 63,338-350$.

HALL K., TAKANO K., ENBERG G., FRYKLUND L., 1976. Studies on the regulation of somatomedins $A$ and B, 178-189. In PECILE A., MÜLLER E. E., Growth hormone and related peptides. Excerpta Med. int. Congr. Ser., n० 381, Amsterdam.

HINTZ R. L., ORSINI E. M., VAN CAMP M. G., 1974a. Evidence for a somatomedin binding protein in plasma. 56th Annu. Meet., Endocr. Soc., Atlanta, USA, A-71 (abstr.).

HINTZ R. L., SEEDS J. M., JOHNSONBAUGH R. E., 1974b. Somatomedin and growth hormone in the newborn. Pediat. Res., 8, 369.

KASTRUP K. W., ANDERSEN H. J., 1975. Studies on somatomedin in newborn and its relationships to the excretion of $\mathrm{GH}$ in urine. Pediat. Res., 9, $683 \mathrm{~A}$.

KOGUT M. D., KAPLAN S. A., SHIMIZU C. S. N., 1963. Growth retardation : use of sulfation factor as a bioassay for growth hormone. Pediatrics, 31, 538.

LUND-LARSEN T. R., BAKKE H., 1975. Growth hormone and somatomedin activities in lines of pigs selected for rate of gain and thickness of backfat. Acta agr. scand., $25,231$.

LUND-LARSEN T. R., SUNBY A., KRUSE V., VELLE W., 1977 Relation between growth rate, serum somatomedin and plasma testosterone in young bulls. J. onim. Sci., 44, 189-194.

PHILLIPS L. S., HERINGTON A. C., DAUGHADAY W. H., 1974. Somatomedin stimulation of sulfate incorporation in porcine costal cartilage discs. Endocrinology, 94, 856-863.

PIERSON M., GRIGNON G., MALAPRADE D., HARTEMANN Ph., 1976. L'activité somatomédine du serum au cours de l'enfance chez le sujef normal et dans les retards de croissance. Ann. Biol. clin., 34, 11-18.

SALMON W. D. Jr., 1972. Investigation with a partially purified preparation of serum sulfation factor : lack of specificity for cartilage sulfation, 180-191. In PECILE A., MÜLLER E. E., Growth and growth hormone. Excerpta Med. int. Congr. ser., n 244, Amsterdam.

SALMON W. D. Jr., DU VALL M. R., 1970a. A serum fraction with " sulfation factor activity » which stimulates in vitro incorporation of leucine and sulfate into protein-polysaccharide complexes, uridine into RNA, and thymidine into DNA of costal cartilage from hypophysectomized rats. Endocrinology, 86, 721-727.

SALMON W. D. Jr., DU VALL M. R., 1970b. In vitro stimulation of leucine incorporation into muscle and cartilage protein by a serum fraction with sulfation factor activity : differentiation of effects from those of growth hormone and insulin. Endocrinology, 87, 1168-1180.

SCHIMPFF R. M., DONNADIEU M., 1973. Quantitative determination of somatomedin in human serum ( ${ }^{35}$ S uptake by embryonic chick cartilage). Biomedicine, 14, 142-147.

STUART M. C., LAZARUS L., MOORE S. S., SMYTHE G. A., 1976. Somatomedin production in the neonatal rat. Horm. Metab. Res., 8, 442-445.

TAKANO K., HALL K., RITZEN M., ISELIUS L., SIEVERTSSON H., 1975. Somatomedin A in human serum, determined by radioreceptor assay. In TAKANO K., Thesis, ISBN 91-7222-133-X, Stockholm.

TATO L., DU CAJU M. V. L., PREVOT C., RAPPAPORT R., 1975. Early variations of plasma somatomedin activity in the newborn. J. clin. Endocr. Metab., 40, 534-536. 
UTHNE K., 1973. Human somatomedins : Purification and some studies on their biological actions. Acta endocr., Suppl., 175, 35 pp.

VAN DEN BRANDE J., L., DU CAJU M.V.L., 1974. An improved technique for measuring somatomedin activity in vitro. Acto. endocr., 75, 233-242.

VAN DEN BRANDE J. L., VAN BUUL S., 1978. The nature of somatomedins and related peptides. Ann. Biol. anim. Bioch. Biophys., 18, 11-19.

VAN WYK J. J., UNDERWOOD L. E., HINTZ R. L., CLEMMONS D. R., VOINA S. J., WEAVER R. P., 1974. The somatomedins : a family of insulinlike hormones under growth hormone control. Rec. Progr. Horm. Res., 30, 259-318.

VAN WYK J. J., UNDERWOOD L. E., LISTER R. C., MARSHALL R. N., 1973. The somatomedins. A new class of growth-regulating hormones ? Am. J. Dis. Child., 126, 705-711. 